Scientific journal

PHYSICAL AND MATHEMATICAL EDUCATION

Has been issued since 2013

Науковий журнал

ФІЗИКО-МАТЕМАТИЧНА ОСВІТА

Видається з 2013.

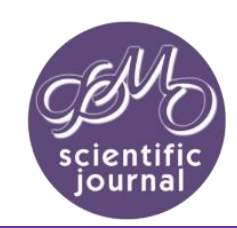

p-ISSN 2413-1571

e-ISSN 2413-158X

DOI: $10.31110 / 2413-1571$

https://fmo-journal.org/
DOI 10.31110/2413-1571-2021-032-6-006

\section{ФОРМУВАННЯ ЧАТ-ЕТИКЕТУ У СТУДЕНТІВ КОЛЕДЖІВ}

\author{
Юлія РУДЕНКо $\square$ \\ Сумський фаховий коледж економіки і торгівлі, Україна \\ yango641@ukr.ne
}

https://orcid.org/0000-0003-3162-1216

УДК 37.015.31:004: 008:377.36:334.38

\section{FORMATION OF CHAT-ETIQUETTE COLLEGES STUDENTS}

\author{
Yuliya RUDENKO $\square$ \\ Sumy professional College of Economics and Trade, Ukraine \\ yango641@ukr.net
}

https://orcid.org/0000-0003-3162-1216

\begin{abstract}
АНОТАЦІЯ
Формулювання проблеми. У статті актуалізується проблема формування культури віртуального спілкування у процес дистанційного навчання для студентів коледжів. Показано, що культура віртуального спілкування (нетикет, мережний етикет, чат-етикет) $\epsilon$ сьогодні невід'ємною складовою культури особистості. Висвітлено особливості створення, розвитку і характеру змін чат-етикету залежно від сфери його застосування. Актуалізовано проблему низького рівня віртуальної комунікації між суб'єктами освітнього процесу і його вплив на якість навчання.

Матеріали i методи. Для вирішення поставленої мети використовувалися теоретичні методи дослідження: аналіз узагальнення наукових джерел $з$ метою розкриття основних положень досліджуваної проблеми; емпіричні методи: анкетування, спостереження, бесіда; статистичні методи опрацювання результатів опитувань респондентів. В експерименті взяли участь студенти і викладачі Сумського медичного коледжу, Сумського машинобудівного коледжу, Сумського медичного коледжу, Конотопського індустріального коледжу. Загальна кількість учасників- 277 студентів і 58 викладачів.

Результати. Формування чат-етикету можливе за такою стратегією: висвітлення $i$ обговорення проблеми, проведення тренінгу, вікторин та конкурсів; включення теоретичного матеріалу з історії розвитку, основ і тенденцій чат-етикету у вивчення дисчиплін ("Інформатика», "Українська мова за професійним спрямуванням", "Зарубіжна література» та інших); спостереження і зворотній зв'язок зі студентами після проведених заходів. Описано тренінг "Чат-етикет: 10 правил культурного віртуального спілкування». Вироблені загальні правила чат етикету, важливі як для дистанційного навчання, так і для повсякденного застосування у спілкуванні з віртуальними спільнотами.

Висновки. Доведено ефективність здійснених формувальних впливів. Спроєктовано перспективні розвідки у напрямку дослідження суголосної проблеми формування етикету відеоконференцій, навчання кібербезпеці $i$ захисту особистої інформації, поліпшенню медіаграмотності.
\end{abstract}

ключовІ СлОвА: чат-етикет; віртуальна комунікація; студенти коледжів; нетикет; мережний етикет.

\begin{abstract}
Formulation of the problem. The article highlights the problem of forming a culture of virtual communication in the process of distance learning for college students. It is shown that the culture of virtual communication (netiquette, network etiquette, chat etiquette) is today an integral part of personal culture. The peculiarities of the creation, development and nature of changes in chat etiquette depending on its scope are highlighted. The problem of low level of virtual communication between the subjects of the educational process and its impact on the quality of education is highlighted.

Materials and methods. To solve this goal, theoretical research methods were used: analysis and generalization of scientific sources in order to reveal the main provisions of the research problem; empirical methods: questionnaires, observations, interviews; statistical methods of processing the results of surveys of respondents. Students and teachers of Sumy College Economics and Trade, Sumy Machine-Building College, Sumy Medical College, Konotop Industrial College took part in the experiment. The total number of participants is 277 students and 58 teachers.

Results. The formation of chat etiquette is possible by the following strategy: coverage and discussion of the problem, training, quizzes and competitions; inclusion of theoretical material on the history of development, basics and trends of chat etiquette in the study of disciplines ("Informatics", "Ukrainian language", "Foreign Literature" and others); observation and feedback from students after the event. The training "Chat etiquette: 10 rules of cultural virtual communication" is described. General rules of chat etiquette have been developed, which are important both for distance learning and for everyday use in communication with virtual communities.

Conclusions. The effectiveness of the formed formative influences is proved. Prospective explorations have been designed to study the common problem of video conferencing etiquette, training in cybersecurity and personal information protection, and improving media literacy.
\end{abstract}

KEYWORDS: chat-etiquette; virtual communication; colleges students; netiquettez.

\title{
ВСТУП
}

Постановка проблеми. Уявлення суспільства про особливості спілкування, жести, пози, символи поведінки уособлює у собі поняття етикету. Він $є$ невід'ємною складовою поняття культури особистості у загальному сенсі і інформаційної культури зокрема. I хоча етикет в певній сфері має свої особливості (військовий, діловий, побутовий тощо), його мета залишається незмінною - не ускладнювати спілкування в спільноті, а сприяти його конструктивному, доброзичливому характеру. Останні десятиріччя відбулося стрімке розширення віртуальної комунікації, що спричинило розвиток культури віртуального спілкування, вироблення правил поведінки на теренах Інтернету. Нова категорія отримала назву нетикету, а також мережного етикету або чат-етикету. Маючи значну спорідненість з етикетом звичайного

\begin{tabular}{|c|c|}
\hline \multirow{2}{*}{$\begin{array}{l}\text { Для } \\
\text { цитування: }\end{array}$} & $\begin{array}{l}\text { Руденко Ю. Формування чат-етикету у студентів коледжів. Фізико-математична освіта, 2021. Том 32. № 6. C. 34-40. DOI: https://doi.org/10.31110/2 } \\
\text { 2021-032-6-006 }\end{array}$ \\
\hline & уденко, Ю. (2021). Формування чат-етикету у студентів коледжів. Фізико-математична освіта, 32(6). 34-40. https://doi.org/10.31110/2413-1571-2021-032-6-006 \\
\hline & $\begin{array}{l}\text { Rudenko, Yu. (2021). Formation of chat-etiquette colleges students. Physical and Mathematical Education, 32(6), 34-40. https://doi.org/10.31110/2413-1571-2021-032- } \\
\text { 6-006 }\end{array}$ \\
\hline citation: & $\begin{array}{l}\text { Rudenko, Yu. (2021). Formuvannia chat-etyketu u studentiv koledzhiv [Formation of chat-etiquette colleges students]. Fizyko-matematychna osvita - Physical and } \\
\text { Mathematical Education, 32(6), 34-40. https://doi.org/10.31110/2413-1571-2021-032-6-006 }\end{array}$ \\
\hline
\end{tabular}


спілкування, чат-етикет створювався і змінювався за власними законами. Він отримав значне переосмислення останні роки, коли письмова мова стала копіювати аналог живого спілкування з його сленгом, скороченнями, абревіаціями. Це спричинило зміну традиційних правил, усталених форм і норм поведінки на нові, менш категоричні, але не менш вимогливі до культури віртуального співрозмовника. Очевидно, що в силу динамічності і стихійності розвитку віртуальних комунікацій, чат-етикет неможливо підпорядкувати строгим правилам, та строгим нормам правопису, але сумісне прагнення найкраще організувати віртуальне спілкування зумовило його мету: у спілкуванні всі повинні дотримуватись принципів терпимості, доброзичливості, адекватності.

За останні три роки через пандемію, спричинену коронавірусом, відбулися майже революційні перетворення в освітньому просторі. Створено унікальні умови для інформаційного обміну, віртуального навчання та спілкування. Всі суб'єкти освітнього простору адаптувалися до незвичних умов віртуального простору і професійно здійснюють навчальну діяльність. Педагоги щодня удосконалюють власну цифрову компетентність: вони успішно проводять відеоконференції, створюють інтерактивні освітні курси, забезпечують автоматизований контроль знань, ефективно використовують інтернет-ресурси для самоосвіти. Молодь також звикла до дистанційної форми навчання і пристосувалася до їі особливостей. Вікові, часові, психологічні і навіть гендерні фактори, створюючи з одного боку перешкоди для адаптації до віртуального простору, з іншого стали вагомими прискорювачами процесів адаптації. Окремі технології опановуються набагато краще педагогами в силу їх досвіду, професіоналізму, інтелекту, деякі, навпаки, краще засвоюються учнями через їх вік, та кмітливість, зумовлену умовами інформаційного середовища, де вони зростають з раннього дитинства.

Втім, не зважаючи на стрімкий успіх такої освітньої діяльності, залишаються проблемними багато складових. Зокрема, академічна доброчесність, інформаційна культура, низький рівень самоорганізації і мотивації, якість навчальних курсів тощо. Вважаючи, що будь-яка освітня діяльність можлива лише за умов забезпечення зворотного зв'язку між суб'єктами, культура віртуального спілкування також потребує посиленої уваги. Адже етикет спілкування, зокрема, правила і домовленості, за яким воно здійснюється, спрямовує подальший вектор партнерства і співпраці. Тому одним із вагомих показників готовності педагогів і учнів або студентів ефективно взаємодіяти в умовах дистанційного навчання $\epsilon$ культура віртуального спілкування, яку найчастіше трактують як мережний етикет або чат-етикет.

Аналіз актуальних досліджень. Проблемами культури переймалась значна кількість вчених філософів, педагогів, філологів та інших. Зокрема, інформаційна культури у філософському дискурсі стала предметом дослідження закордонних і вітчизняних учених.

Особливості комп'ютерного дискурсу вивчались М. Федорів (2021). Нею схарактеризовано найважливіші лексичні особливості комп'ютерного спілкування, ознаки, типи іжанри комп'ютерного спілкування. Визначала типові риси віртуального спілкування і його особливості Л. Харчук (2020), яка аналізує мережний мовленнєвий етикет в умовах сучасної комунікації і наводить рекомендації до його удосконалення.

С. Зайцева приділяє увагу вивченню мовних засобів під час спілкування в інтернеті україномовних користувачів Нею розглянуто орфографічні, стилістичні особливості такого спілкування, зокрема, англіцизми мови інтернету, абревіація і сленг, а також причини їх появи і популярності. Вона доходить висновку, що віртуальна мова спілкування через їі спорідненість із усною мовою, зокрема миттєвість відповіді, набуває рис окремого стилю, головною особливістю якого $\epsilon$ усно-розмовна манера спілкування з його правилами (Зайцева, 2021).

Проблеми мережного спілкування молоді, такі як кібербулінг, тролінг, агресію досліджує С. Паркс і обґрунтовує стійку кореляцією між віком, частотою соціальної взаємодії і частотою негативних насильницьких атак у мережі (Рark et al., 2014). Схожі дослідження проводять Д. Петер та М. Патті і, аналізуючи вікові, психологічні особливості людини, визначають фактори, що впливають на онлайн поведінку і прогнозовані наслідки такої поведінки (Peter et al., 2019).

Мережний етикет, як феномен сучасної віртуальної комунікації досліджували, І. Пахомова (Пахомова, 2018), С. Бибик (Бибик, 2015). Проблеми інтерактивного спілкування у дистанційному навчанні вивчались О. Пінчук (Пінчук, 2015) С. Науменко (Науменко, 2013). Суголосна думка дослідників - через особливості мережного спілкування у цифровому просторі не можна примушувати до дотримання жорстких правил і норм мовного етикету, формування етикету у мережі має носити характер спільного порозуміння і ненав'язливих, але дієвих рекомендацій.

Вказує на значущість сформованості культури віртуальної комунікації Л. Нос з позицій ІКТ і пропонує алгоритм формування соціокультурної компетентності засобами IKT в рамках ознайомлення з комунікативним етикетом: реалізація міжпредметних зв'язків дисциплін гуманітарного циклу; організація навчання як дослідження (проєктна технологія); аналіз автентичних текстів та моделювання соціальних ролей; створення навчально-дослідних груп (онлайн-групи) (Nos \& Stakhiv, 2021).

Отже, в умовах дистанційного навчання віртуальний зворотній зв'язок $є$ настільки актуальним, що очевидною стала закономірність: чим вищий рівень культури віртуального спілкування (чат-етикету) між педагогами і суб'єктами навчання, тим ефективніше відбувається процес навчання. Науковою спільнотою доведено, що стресові чинники, зумовлені проблемами у якості зворотнього зв'язку, ведуть до негативних наслідків, емоційного вигоряння і зниження ефективності навчання (Minihan et al., 2020). Тому проблеми якості віртуальної взаємодії зумовили дослідження чатетикету та шляхів його удосконалення.

Якісні зміни у віртуальному спілкуванні за час пандемії досліджували і важливість формування соціокультурної компетентності висвітлюють у наукових працях А. Мельниченко, Т. Желязкова (Melnychenko \& Zheliaskova, 2021) i А. Богуш, Т. Королева (Bogush et al., 2021).

Проте вивчення чат-етикету у дистанційному навчанні, аналіз його проблем і труднощів, що гальмують процес ефективної взаємодії між учасниками освітнього процесу, не було предметом дослідження.

Мета статті. 3 огляду на актуальність теми метою статті $€$ висвітлення стану сформованості чат-етикету у студентів коледжів та надання практичних рекомендацій щодо його формування. 


\section{МЕТОДИ ДОСЛІДЖЕННЯ}

Для вирішення поставленої мети використовувалися теоретичні методи дослідження: аналіз і узагальнення наукових джерел з метою розкриття основних положень досліджуваної проблеми; емпіричні методи: анкетування, спостереження, бесіда; статистичні методи опрацювання результатів опитувань респондентів.

\section{РЕЗУЛЬТАТИ ТА ЇХ ОБГОВОРЕННЯ}

Дослідження віртуальних комунікацій між викладачами і студентами тривало впродовж 2020-2021 року у коледжах м. Суми та Сумської області. Об'єктом дослідження став чат-етикет між студентами й викладачами Сумського медичного коледжу, Сумського машинобудівного коледжу, Сумського медичного коледжу, Конотопського індустріального коледжу. Загальна кількість учасників- 277 студентів і 58 викладачів.

На першому етапі нашого дослідження (лютий 2020 року) для виявлення рівня дотримання чат-етикету ми запропонували пройти онлайн-анкетування всім учасникам освітнього процесу. Для цього було створено анкету, яка містила однакові запитання і для студентів і викладачів.

Анкета містила такі запитання:

1. Який застосунок для зв'язку ви використовуєте найчастіше?

2. Чи дратує вас надмірна кількість смайликів і стикерів?

3. Як ви ставитесь до голосових повідомлень?

4. Чи доречно турбувати з навчальних або робочих причин у вихідні дні?

5. Як ви ставитесь до групових вітань із святами?

6. Яке ваше ставлення до помилок у повідомленні?

7. Оцініть, за вашою думкою, рівень дотримання культури віртуального спілкування у освітньому процесі за 10бальною шкалою.

Фрагмент анкети представлений на рисунку.

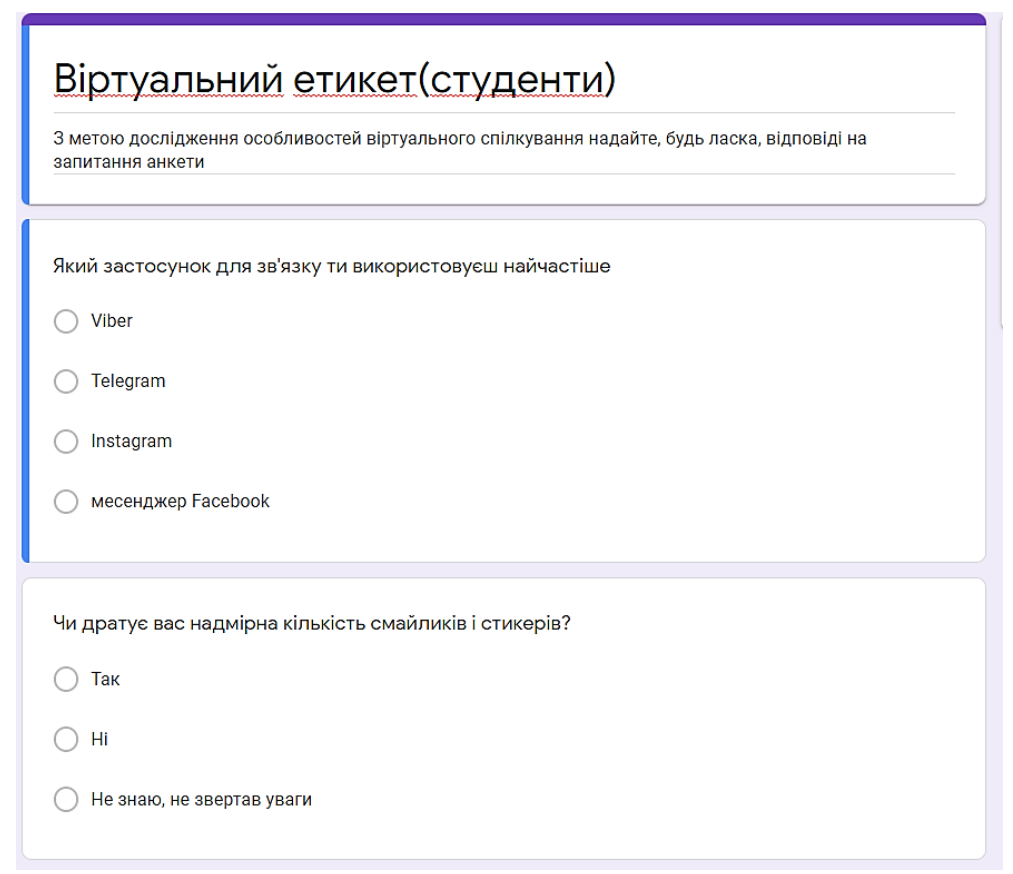

Рис. 1. Фрагмент гугл-форми опитувальника

Представляємо аналіз результатів анкетування у вигляді гістограм розподілу відповідей викладачів і студентів.

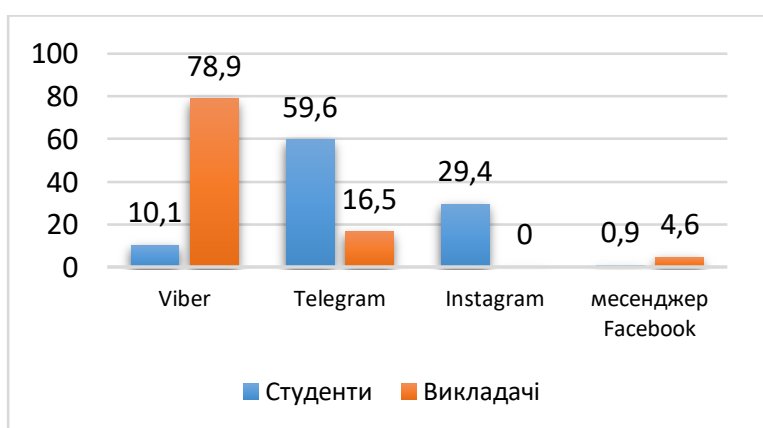

Рис. 2. Розподіл відповідей студентів і викладачів на запитання 1 (Який застосунок для зв'язку ви використовуєте найчастіше?)

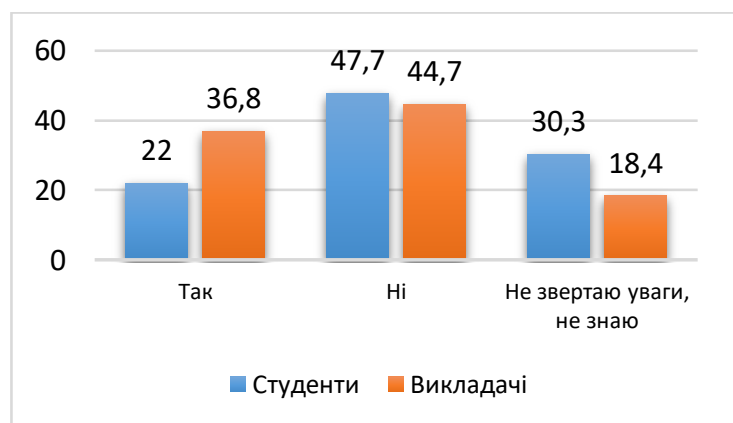

Рис. 3. Розподіл відповідей студентів і викладачів на запитання 2 (Чи дратує вас надмірна кількість смайликів і стикерів?) 


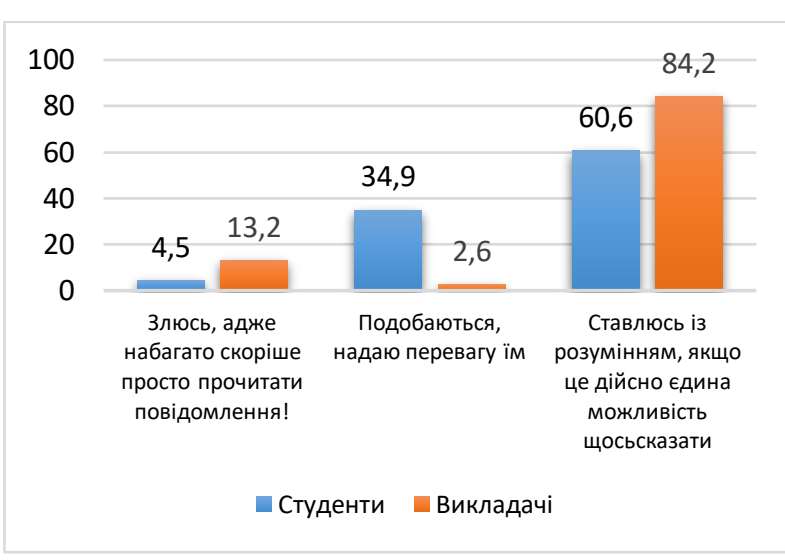

Рис. 4. Розподіл відповідей студентів і викладачів на запитання 3 (Як ви ставитесь до голосових повідомлень?)

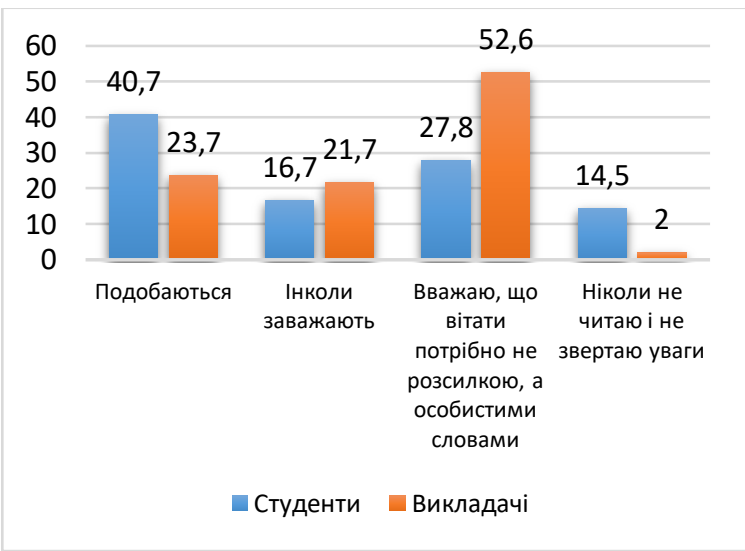

Рис. 6. Розподіл відповідей студентів і викладачів на запитання 5 (Як ви ставитесь до групових вітань із святами?)

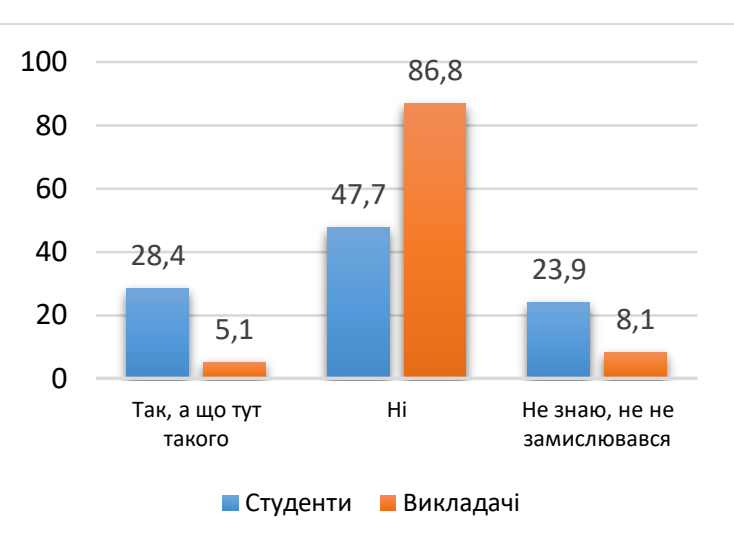

Рис. 5. Розподіл відповідей студентів і викладачів на запитання 4 (Чи доречно турбувати з навчальних або робочих причин у вихідні дні?)

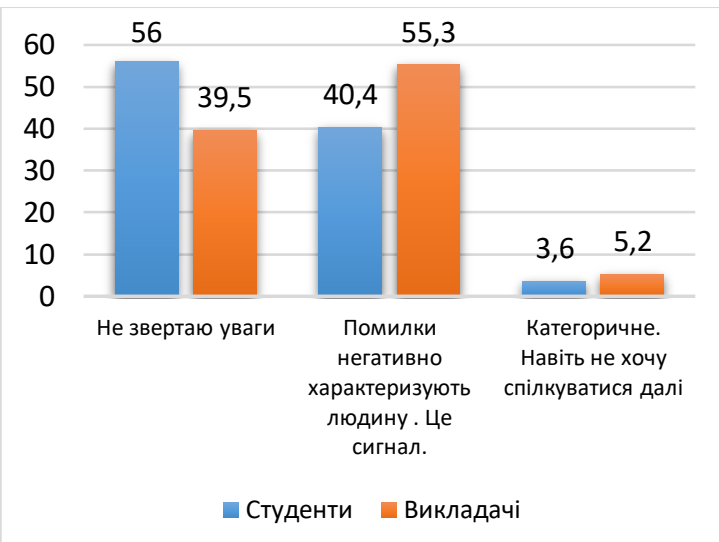

Рис. 7. Розподіл відповідей студентів і викладачів на запитання 6 (Яке ваше ставлення до помилок у повідомленні?)

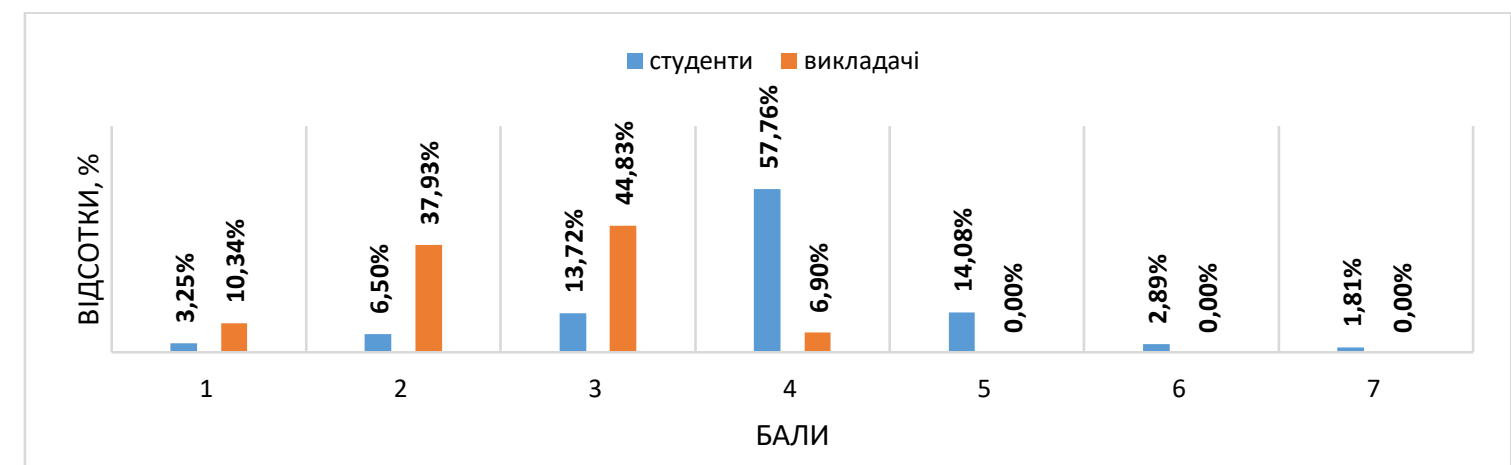

Рис. 8. Розподіл відповідей студентів і викладачів на запитання 7 (Оцініть, за вашою думкою, рівень дотримання культури віртуального спілкування у освітньому процесі за 10-бальною шкалою)

Аналіз відповідей і порівняння тверджень викладачів і студентів виявив таке.

Найпопулярніший застосунок для студентів - Телеграм, для викладачів - Вайбер.

Майже 50\% і студентів і викладачів спокійно ставляться до смайлів, голосові повідомлення 84\% викладачів і 60\% студентів визнають тільки у разі того, що це єдина можливість щось сказати.

Недоречним турбувати у вихідні з робочих моментів визнається 86\% викладачів і лише $47 \%$ студентів.

Тільки 23,7\% викладачів і 40,7\% студентів подобаються групові вітання зі святами.

Не звертають уваги на помилки у повідомленнях 56\% студентів і майже $40 \%$ викладачів, але для решти - це сигнал, що негативно характеризує людину.

Середній бал оцінки студентами якості культури віртуального спілкування за 10-бальною шкалою - 4,88, викладачами - 3,42.

Отже, за результатами анкетування можна зробити наступні висновки: ставлення до культури віртуального спілкування у студентів і викладачів різниться. Те, що для студентів $€$ нормою (неграмотність, дзвінки у вихідні дні, голосові 
повідомлення), для викладачів може бути неприйнятним або дратівливим фактором. Водночас, всі суб'єкти освітнього процесу прагнуть до взаєморозуміння, взаємоповаги і результативності.

Таким чином, нами було проаналізовано синтезовано і оприлюднено особливості чат-етикету, які викликали роздратування у віртуальних спільнотах, непорозуміння і агресію. У результаті тривалого спостереження за віртуальним спілкуванням при дистанційному навчанні, проведеного анкетування та його аналізу, опрацювання наукових джерел, обміну думками з педагогами була розроблена стратегія формування чат-етикету студентів. Вона включала такі етапи:

1. Обговорення проблеми та обґрунтування ії значущості на методичних об'єднаннях викладачів. Окреслення вектору формування чат-етикету, узгодження його основних правил.

2. Популяризація основоположних норм чат-етикету через проведення тренінгу «Чат-етикет: 10 правил культурного віртуального спілкування» зі студентами всіх груп із залученням викладачів та сторонніх гостей (представників різних професій).

3. Проведення вікторини «А чи знаєте ви? Цікавинки чат-етикету» та конкурсу «Збери пазл: Інтернет, який ми хочемо».

4. Викладання основ чат-етикету шляхом його включення в курс окремих дисциплін, зокрема, «Інформатика», «Українська мова за професійним спрямуванням» та інших.

5. Спостереження і зворотній зв'язок зі студентами після проведених заходів.

6. Аналіз результатів та перевірка ефективності формування чат-етикету.

Тренінг передбачав дискусію про культуру віртуального спілкування, оприлюднення результатів анкетування як студентів, так і викладачів, а також демонстрацію презентації основних правил поведінки у віртуальному просторі. Для того, щоб привернути увагу студентів і показати значущість і важливість кожного правила, кожний слайд-правило супроводжувався дотепними прикладами з життя, копіями чат-повідомлень. Наприкінці заходу були визначені логічні, послідовні правила чат-етикету, дотримання яких сприяє покращенню віртуального спілкування.

Це такі правила:

1. У діловому, віртуальному спілкуванні, в першу чергу, потрібно привітатися і представитися.

2. Не зловживати смайликами

3. Пам'ятати про межі особистого простору, не турбувати людей з навчання у вихідні та поза його часом.

4. Не дробити повідомлення (одне повідомлення -одне слово)

5. Не допускати помилок, перевіряйте текст на орфографію та логіку

6. Висловлювати думки ясно і без зайвих емоцій

7. Не зловживати голосовими повідомленнями

8. Мати терпіння дочекатись відповіді

9. Не надсилати зайвого у групові чати

Фрагмент тренінгу представлений на рисунку.

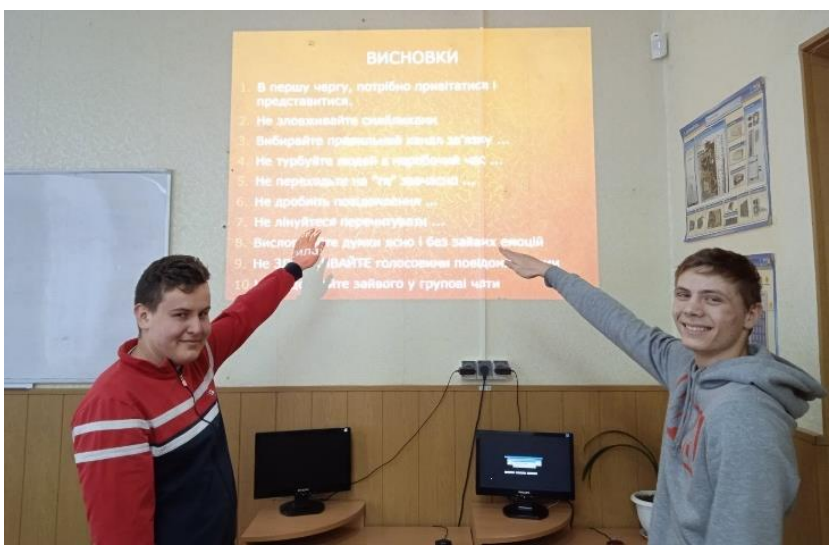

Рис. 9. Фрагмент тренінгу «Чат-етикет: 10 правил культурного віртуального спілкування» у групі коледжу

Спостереження за поведінкою студентів під час тренінгу, їх активність і реакція не певні правила підтверджували: вони визнають проблему з культурою чат-етикету не тільки у себе, а й у свого оточення. Прохання поширити презентацію, провести тренінг серед друзів та близьких, додаткові ідеї і пропозиції щодо удосконалення віртуального спілкування показали небайдужість і прагнення покращувати рівень власної культури віртуального спілкування.

Протягом місяця проводились додаткові, окреслені у стратегії, заходи - конкурс, вікторина, міні-лекції на заняттях 3 «Інформатики» та «Української мови за професійним спрямуванням» з історії розвитку мережного етикету, логіки його створення, тенденцій розвитку. За результатами формувальних впливів було проведене повторне опитування, в якому викладачі і студенти знову оцінювали рівень чат-етикету у освітньому процесі.

Більшість учасників експерименту вказали: сумісне дотримання певних узгоджених правил чат-етикету привело до зниження конфліктів, непорозумінь, взаємоповаги у позаурочний час.

\section{ВИСНОВКИ ТА ПЕРСПЕКТИВИ ПОДАЛЬШОГО ДОСЛІДЖЕННЯ}

Одним із вагомих показників готовності педагогів і учнів або студентів ефективно взаємодіяти в умовах дистанційного навчання $€$ культура віртуального спілкування - мережний етикет або чат-етикет. Всі учасники освітнього процесу розуміють значущість чат-етикету і прагнуть до його покращення. Рівень сформованості чат-етикету впливає на 
ефективність навчання у дистанційних умовах. Чат-етикет має певні особливості в силу характеру його створення, розвитку і поширення. Незважаючи на них, головні принципи залишаються незмінними - віртуальне спілкування, як і реальне має базуватися на принципах доброзичливості, терпимості і адекватності. У статті висвітлені проблеми якості віртуального спілкування, які досліджені шляхом анкетування студентів і викладачів коледжів.

Серед них: суттва відмінність поглядів викладачів і студентів на деякі аспекти чат-етикету (вимоги до грамотності, дотримання меж особистого простору, тощо); незнання, а тому і недотримання норм ведення культурного діалогу; окремі випадки нетерпимості або агресії. Позитивним є суголосне прагнення всіх суб'єктів освітнього процесу до взаєморозуміння, взаємоповаги і ефективної віртуальної взаємодії. Зважаючи на визначені проблеми було розроблено і впроваджено стратегію формування чат-етикету студентів у коледжах.

Стратегія включала такі етапи: обговорення проблеми і окреслення вектору формування чат-етикету 3 викладачами коледжів Сумської області; популяризація основоположних норм чат-етикету (тренінг, вікторина, конкурс); включення теоретичного матеріалу з історії розвитку, основ і тенденцій чат-етикету в курс вивчення дисциплін «Інформатика», «Українська мова за професійним спрямуванням» та інших; спостереження і зворотній зв'язок зі студентами після проведених заходів.

Проведене дослідження крім зазначених результатів засвідчило актуальність і невирішеність проблем, серед яких формування у студентів етикету відеоконференцій (Zoom-етикету), навчання кібербезпеці і захисту особистої інформації, поліпшення медіаграмотності.

Перспективи подальших досліджень вбачаємо у розробці дієвих шляхів, спрямованих на вирішення зазначених проблем, у вивченні дієвих закордонних моделей і прогресивного досвіду з означеної тематики.

\section{СПИСОК ВИКОРИСТАНИХ ДЖЕРЕЛ}

1. Федорів, О. В. (2021). Про особливості комп'ютерного дискурсу. https://www.vesna.org.ua/txt/fedorivm/jargon.html

2. Харчук, Л. Н. (2020). Мережевий мовленнєвий етикет в умовах сучасної комунікації. Інформація, комунікація, суспільство 2020, (9), 128-129. Видавництво Львівської політехніки. http://ena.lp.edu.ua:8080/handle/ntb/52767

3. Зайцева, С. (2021). Інтернет-сленг в україномовному медіа- просторі. Науковий вісник Міжнародного гуманітарного університету, (32), 34-36 http://lingvodnu.com.ua/arxiv-nomeriv/lingvistika-lingvokulturologiya-2011/internet-sleng-vukra\%D1\%97nomovnomu-mediaprostori/

4. Sung-Chul, L., Jaeyoon, S., Eun-Young, K., Seongho, P., \& Juho, K. (2020) The relationship between online activities, netiquette and cyberbullying. Proceedings of the 2020 CHI Conference on Human Factors in Computing Systems. Children and youth services review, (101), 74-81. http://doi.org/10.1145/3313831.3376609

5. Peter, Dr. J., Valkenburg, P. M., \& Schouten, A.P. (2019). Developing a Model of Adolescent Friendship Formation on the Internet. CyberPsychology \& Behavior, (50), 423-430. http://doi.org/10.1089/cpb.2005.8.423

6. Пахомова, И.Н. (2018). Речевой этикет на интернет-форумах. Полилингвиальность и транскультурные практики. https://cyberleninka.ru/article/n/rechevoy-etiket-na-internet-forumah

7. Бибик, С. М. (2015). Нетикет, або мережевий етикет. Культура слова, (82), 125-127.

8. Пінчук, О. П. (2015). Історико-аналітичний огляд розвитку соціальних мережних технологій і перспектив їх використання у навчанні. Інформаційні технології і засоби навчання, 48(4), 14-34. https://doi.org/10.33407/itlt.v48i4.1267

9. Науменко, С. О. (2013). Проблема інтерактивного спілкування у дистанційному навчанні. Науковий вісник Мелітопольського державного педагогічного університету. Серія: Педагогіка. (6), 121-124.

10. Nos, L. C., \& Stakhiv, M. O. (2021). The Use Of Information And Communication Technologies As A Means For Prospective Primary School Teacher's Social And Cultural Competence Formation. Information Technologies and Learning Tools, 82(2), 166-181. https://doi.org/10.33407/itlt.v82i2.3167

11. Конюкова, І. Я., \& Сидоровська, Є. А. (2021). Цифровий етикет комунікативної культури XXI століття. Вісник Національної академії керівних кадрів культури і мистецтв, 3. 26-30. http://elib.nakkkim.edu.ua/handle/123456789/3270

12. Melnychenko, A., \& Zheliaskova, T. (2021). Transformation of educational process in Covid-19 pandemic: a case of Igor Sikorsky Kyiv polytechnic institute. Advanced Education, 8(18), 4-10. https://doi.org/10.20535/2410-8286.237575

13. Bogush, T. A., Korolova, O. V. \& Popova B. C., (2021) Development of university students' linguocultural competence under conditions of coronavirus pandemic: ukrainian dimension", Advanced Education, 17, 103-117. https://eric.ed.gov/?id=EJ1305562

14. Minihan, E., Adamis, D., Dunleavy, M., Martin, A., Gavin, B., \& McNicholas, F. (2019). COVID-19 related occupational stress in teachers in Ireland. International Journal of Educational Research Open, https://www.sciencedirect.com/science/article/pii/S2666374021000844.

\section{REFERENCES (TRANSLATED AND TRANSLITERATED)}

1. Fedoriv, M. (2021). Pro osoblyvosti kompiuternoho dyskursu [About the peculiarities of computer discourse] https://www.vesna.org.ua/txt/fedorivm/jargon.html (in Ukrainian).

2. Kharchuk, L. N. (2020). Merezhevyi movlennievyi etyket v umovakh suchasnoi komunikatsii [On the peculiarities of computer discourseNetwork speech etiquette in modern communication] Informatsiia, komunikatsiia, suspilstvo 2020 - Information, communication, society 2020, (9), 128-129 http://ena.Ip.edu.ua:8080/handle/ntb/52767 (in Ukrainian).

3. Zaitseva, S. (2021). Internet-slenh v ukrainomovnomu media- prostori [Internet slang in the Ukrainian-language media space]. Naukovyi visnyk Mizhnarodnoho humanitarnoho universytetu - Scientific Bulletin of the International Humanities University, 32, 34-36. http://lingvodnu.com.ua/arxiv-nomeriv/lingvistika-lingvokulturologiya-2011/internet-sleng-vukra\%D1\%97nomovnomu-media-prostori/ (in Ukrainian).

4. Sung-Chul, L., Jaeyoon, S., Eun-Young, K., Seongho, P., \& Juho, K. (2020). The relationship between online activities, netiquette and cyberbullying. Proceedings of the 2020 CHI Conference on Human Factors in Computing Systems. Children and youth services review, 101, 74 81. http://doi.org/10.1145/3313831.3376609

5. Peter, Dr. J., Valkenburg, P. M., \& Schouten, A.P. (2019). Developing a Model of Adolescent Friendship Formation on the Internet. CyberPsychology \& Behavior, (50), 423-430. http://doi.org/10.1089/cpb.2005.8.423

6. Pakhomova, Y.N. (2018). Rechevoi etyket na ynternet-forumakh [Speech etiquette on online forums]. Polylynhvyalnost y transkulturnble praktyky - Polylingualism and transcultural practices, 5, 89-93. https://cyberleninka.ru/article/n/rechevoy-etiket-na-internet-forumah (in Russian).

7. Bybyk, S. M. (2015). Netyket, abo merezhevyi etyket [Netiquette, or network etiquette.] Kultura slova-The culture of the word, 82, 125-127. 
(in Ukrainian).

8. Pinchuk, O. P. (2015). Istoryko-analitychnyi ohliad rozvytku sotsialnykh merezhnykh tekhnolohii i perspektyv yikh vykorystannia u navchann [Historical and analytical review of the development of social network technologies and prospects for their use in education]. Informatsiini tekhnolohii i zasoby navchannia - Information Technologies and Learning Tools, 48(4), 14-34. https://doi.org/10.33407/itlt.v48i4.1267 (in Ukrainian).

9. Naumenko, S. O. (2013). Problema interaktyvnoho spilkuvannia u dystantsiinomu navchanni [The problem of interactive communication in distance learning.] Naukovyi visnyk Melitopolskoho derzhavnoho pedahohichnoho universytetu. Seriia: Pedahohika - Bulletin of Melitopol State Pedagogical University. Series: Pedagogy, 6, 121-124. (in Ukrainian)

10. Nos, L. C., \& Stakhiv, M. O. (2021). The Use Of Information And Communication Technologies As A Means For Prospective Primary School Teacher's Social And Cultural Competence Formation. Information Technologies and Learning Tools, 82(2), 166-181. https://doi.org/10.33407/itlt.v82i2.3167

11. Koniukova, I. Ya., \& Sydorovska Ye. A. (2021).Tsyfrovyi etyket komunikatyvnoi kultury KhKhl stolittia [Digital etiquette of communicative culture of the XXI century.]. Visnyk Natsionalnoi akademii kerivnykh kadriv kultury i mystetstv - Bulletin of the National Academy of Management of Culture and Arts, 3, 26-30. http://elib.nakkkim.edu.ua/handle/123456789/3270 (in Ukrainian).

12. Melnychenko, A., \& Zheliaskova, T. (2021). Transformation Of Educational Process In Covid-19 Pandemic: A Case Of Igor Sikorsky Kyiv Polytechnic Institute. Advanced Education, 8(18), 4-10. https://doi.org/10.20535/2410-8286.237575

13. Bogush, T. A., Korolova, O. V., \& Popova B. C., (2021) Development of university students' linguocultural competence under conditions of coronavirus pandemic: ukrainian dimension", Advanced Education, 17, 103-117. https://eric.ed.gov/?id=EJ1305562

14. Minihan, E., Adamis, D., Dunleavy, M., Martin, A., Gavin, B., \& McNicholas, F. (2019). COVID-19 related occupational stress in teachers in Ireland. International Journal of Educational Research Open, https://www.sciencedirect.com/science/article/pii/S2666374021000844.

\section{(cc) EY-NC-SA}

This work is licensed under Creative Commons Attribution-NonCommercial-ShareAlike 4.0 International License. 